\title{
SUMMARY OF THE PROCEEDINGS OF THE SYMPOSIUM "THE STATE OF NATURE CONSERVATION IN SOUTHERN AFRICA"
}

\author{
O MARTINY \\ President \\ Wildlife Society of Southern Africa \\ PO Box 44189 \\ Linden \\ 2104
}

Let me start by saying that the Symposium has, to a very large extent, been a report back from many departments and from many sections within and without the Republic of South Africa, and we are very grateful to the neighbouring States for the valuable contribution they made, in telling us what they are doing.

I think this is a birthday celebration and not a funeral celebration, and therefore I hope that we can go away from here with some positive thoughts, rather than to bow down and get scared off by the heavy clouds that are hanging over the whole question, not only of conservation, but of the whole human population explosion survival.

I must, however, without going into details regarding each person and what they have given us, mention just one or two. The main one, of course, as far as I am concerned, is Dr R Knobel, whose tireless energy over the many years has really meant building up the Kruger National Park.

The second part is to thank his staff, and all the people who work with him. As you can see, they give him grey hairs but when you look at some of them, they also have grey hairs. It's a heavy task of organising and running this large organisation.

Thirdly, I would like to thank the speakers, without mentioning them individually. To me, the most important thing that emerged in this Symposium was the absolute dedication with which the different speakers spoke, of where they were working in a field in which they thoroughly believed and they sold it to us with all the sincerity that was possible.

I think that all of you in this field, are to be congratulated and we have to thank you that we have people like you to direct conservation in and around our borders. From the top of the ladder with the biggest, down to the people with the smallest, it has been hard work and it has been very difficult. No reserve has just been created easily - with the exception, of 
course, that Dr Knobel goes up in a plane, looks out of the window and says, "That would be nice", and it was done. Hocus, pocus. We hope he does it again some time.

The other aspect which I found terribly interesting, was - I don't know if all of you have experienced it - the communication which took place at this Symposium. As in so many cases, the real importance of a conference is afterwards, especially after one has had a couple of drinks and one's tongue loosens up thereby meeting each other and gaining a respect for each other and a mutual understanding.

My plea at this Symposium would be that scientists especially, see eye to eye, for they are always at each other because one is pinching the other's research, or the one does not agree with the other. May I make a plea that as we have got to know each other, and as we have got respect for each other, in future - before we criticise, communicate, and maybe we will agree instead of fighting each other.

I think that today is a very special day in which we are honouring the founder of the whole question of conservation in southern Africa, namely President Paul Kruger. And when we think back to the days when he did this and even in later years when Stevenson-Hamilton had to fight the very difficult battle, we must remember that in those days man set out to conquer the wilderness. Anybody who considered conserving it, was thought of as a crank. And yet, what they have persisted with, allows us to reap the benefits today. So if we encounter further battles and difficulties and seemingly hopeless situations, please just think back that if they could do it, we should be able to go further as well. Despite difficulties, we have to win somewhere along the line.

The outlook, of course, in those days was that the wilderness had to be tamed. The outlook today is that there is no more land to spare. And I do not think that this should dissuade us from attempting to get as much land conserved now and in the very near future, as we possibly can whatever the battles involved - because if we do not do it now, maybe there will not be any further opportunity to do so.

Population explosion has popped up its head over and over again. It is something with which all of us are becoming more and more concerned. However, I wish to put in a word of warning: it is easy to say control population, but as you know, sex has come to stay and unfortunately, you cannot legislate on it and you cannot really legislate on birth control. That is the surest fuel that you can add to any revolution. You cannot do it by force, the only other way of doing it is by education. To implement birth control far more thought needs to be devoted to it and we must try to use every conceivable method that we can think of, to limit this population explosion amongst all people. I think the security that we require, as I said, lies in the field of education. We do not have to indoctrinate people, but we have at least got to make them understand so that the decisions they make can be balanced.

To this problem I would like to add, after the excellent talk that $\mathrm{Mr}$. 
Immelman gave us, (which many speakers said brought us back to reality), the immense problems that agriculture faces in this country. We are dealing with a land that is being despoiled, eroded and lost in encroaching desert - lack of water. The significant part of the paper was that by the year 2000 , more or less, there will be no adequate water supply or land available. My question is: Am I worried merely for the next twenty years, when I may still be alive, or should I worry about my child who will be alive beyond that? And if we are going to take measures similar to the population explosion, surely we don't wait until the over-used land is spoilt and degraded even further before we take action. When I said it was difficult to legislate on sex, it is just as difficult for any government politically to legislate on land.

I think the time has come when one must think of land, not as belonging to yourself, but that you are the custodian of that land for the generations to come. I would like to see action now, before we reach the situation where a farmer is told that a portion of his land should be rested and conserved by law. If this were to be the case, the food prices would go up, but does it really matter? If you take the price of food today, compared to the price of food ten years ago, we have had no control over that. It has just rocketed sky high and although I am probably one of the fattest here, none of you look starved - you are all managing. But why must we wait until the year 2000, when so much more soil has gone into the sea, before we say, "Now we are going to turn the screws on. Now we must have a dictatorship to put it back into order". Surely the time has come that if the farmer worked only part of his land and had to conserve part of it, that land might still recover and be conserved as part of the overall conservation policy. I put it to you as a thought. Why wait and leave it to our children? Are we too scared to tackle these problems now? Apparently we have it so good and we are so selfish that we are not prepared to take action. We are leaving it for the future and we do not appreciate that we can do with less and not more.

Most of the speakers today and over the last few days were optimistic. I think this is right. It's a birthday and not a funeral. But this optimism is qualified by many "but's" and "if's". I think that reasons for conservation were conflicting, especially the one justifying it on economic grounds: not one of your speakers really believed in the economics of the matter. If you were mercenary, none of you would be in this job. You'd be out in business, you'd have earned the money and bought your own private game farm for your own selfish ends, for hunting or relaxation. But you're in the conservation game for idealism and belief in the conservation action. However,we have to justify this to others, to try to allow us to keep or conserve what we have got and to extend it. Mr de la Bat, of course, had a wonderful case. He proved the economics of it. I think that Mr Reilly in the Swaziland setting, also proved that there are other reasons for conservation. But I would like to say to you, if conservation or game farming were an economic proposi- 
tion, why are so many of you farmers here not in game farming? Because you do not believe it yet and you know it is not that easy. But there are glimmerings of hope in this. There are game farms that are in fact profitable. I was very glad recently to hear, and Dr Bigalke, of course, is involved in this in the northern Cape, that with the change in prices, springbok farming is now becoming competitive with sheep farming in the same area; and obviously the utilisation of the veld is enhanced and the conservation of the land for the future is better.

There are other examples where this approach works, and to go to extremes, go to the Lion Park - it pays. But whether you call that conservation, of course, is a different story. But I think far more is needed and I know many people are trying to find and prove that conservation pays. But don't let us sell a concept which we ourselves are not sure of as yet. I would like to say to the farmer interested in conservation, that he should attempt to show that even part of his farm pays under conservation. Nobody says that cattle and sheep and planted crops alone are the answer to our future food problems. There are many features that we are ignorant of. Let's try to provide the proof.

To the businessman I would say this: Those of you who own game farms from money earned in other fields, think very seriously that twenty years from now, that ideal that you have conserved may not be there any longer - unless you entrench it in clauses and give it to national parks, to provinces. That's the best chance that there is of conserving it. And I mean this very sincerely, that if you want that land which you've worked your life for as your ambition to have as a reserve, if you try to hang on to it and pass it on to your children, economics will come in and it will go under the plough. If it is given to the State, it will be conserved forever and that could be your contribution and future memorial.

Let me switch to another aspect. Another reason why conservation is required is that we must not allow any species of plant or animal to become extinct. I am referring to the medical and related values. I'll try very briefly, without detailed knowledge, to give you a few examples. Firstly, I want to mention that, as you all know, throughout the ages, plants have formed the basis of the medicines used by man. And even in modern times, (juggling with all the funny little organic chemistry molecules and particles of it), invariably the medicine is discovered from a plant before it is synthesized into the medicines that we use today.

Go back into history to a thing like the foxglove. If it were extinct we would not have digitalis. Let's come nearer to modern times and take cortisone. The first cortisone was extracted from bulbs which came out of East Africa and certainly provided a major trade. Penicillin, streptomycin, which came out of measly little moles in the sewers under a city and because somebody observed that the bacteria in the vicinity were killed, we have these wonders of modern medicine. They, in part, are helping the population explosion the wrong way round, but let us 
remember that it is of value to ourselves to keep healthy and strong, but it doesn't necessarily mean that we have got to add on many, many more individuals.

The Rh factor: this was discovered in blood while dealing with the question of jaundiced babies. The factor was found because of an inter-action between the blood of a rhesus monkey - and that's where the "Rh" comes from - and human blood. If rhesus monkeys were extinct, we would possibly not have found this at all.

Furthermore, there is the question of smallpox. We all get vaccinated against it. If we didn't have cows, maybe we wouldn't have had smallpox. But let's go further and mention that a disease in cattle known as "elephant's skin disease" is also found in wildebeest. A serum has been developed from wildebeest which is now used in cattle to stop this disease and thereby provides us with many valuable cattle hides that otherwise would have been lost. There are simple questions in this which are terribly fascinating. As you know, there is competition in nature. The dominant one takes over and there are likewise many diseases where you can cure one disease by giving a person another disease. We have it in tuberculosis and in leprosy where there are many bacilli and the one gives you a cross immunity against the other. This is a field which Onderstepoort and veterinarians around the world are far ahead of human medicine in researching these diseases, and much of what we have learned in medicine has come from animal research - but mainly on domestic animals. When Dr Pienaar gave us that excellent outline of the vast research that is going on in the national parks and, of course, at the provincial level and elsewhere, it is clear that scientists are just scratching the surface.

We have in the past used insects: honey bees to America, dung beetles to Australia, lots of other controlled insects and pests like the cochineal on the prickly pear. There are so many of these unknown factors, of some little creepy crawly thing sitting somewhere, that we know nothing about at this stage. Can we afford to destroy it before we know whether this may be a possible aid that we require? At present they are researching on plants to find anti-cancer agents. In laboratories they are still constantly researching on any plant to find medicines and other uses. Comes our pollution, which plant can take it, which can survive, which can hold on to the soil before it goes, which can revive the soil to bring it back into use. All of these are questions that we do not know enough about and we are all amateurs or we are just scratching the surface to try to find out about it. Destroy that plant or that animal and we will never get the answer. I think this is a very powerful aspect that we must think of. If we think of the worst, apart from the population explosion, one of the ways of curing it, of course, is the atomic bomb. But for those of us who might survive, which plants and which animals will be able to survive with us? How many are sensitive, how many are not sensitive and why? There are many angles. I do not think that we should 
should be thought of, always accentuating conservation into the entire problem in as strong as possible a way. Furthermore, such a department should become essential, not only internally in the Republic of South Africa, but also beyond our borders, where there should be co-operation, at the highest level. This is not the time for us to have so many different departments involved and mixed up, where so very often, A doesn't know what $\mathrm{B}$ is doing and through the lack of co-ordination it means time and waste of time and makes effective conservation very difficult. I would like a reassessment of this whole question of a Department of Conservation and Environment in its own full right. I would like a reassessment on the whole question which was brought up by $\mathrm{Dr} \mathrm{Du}$ Plessis, of provincial reserves that really have the status of national parks, of even municipal reserves that really have the status of what should be provincial reserves, and of the question of what should be for tourism primarily and what should be wilderness or total conservation and, of course, the marine parks come into this - what's in the sea and what's on the land nearby. Should we not have a reassessment and a set of values drawn up soon, on deciding basic criteria by which people administer reserves, basic criteria which will be acceptable to all of you, but will lay down a set of rules by which people have to look after reserves. And should we not entrench as many of the real valuable reserves in this country under national, rather than allow it to be under provincial control?

Mr Reilley mentioned very clearly that in Swaziland, under their beautiful soil, lies coal. There is a potential for sugar and we all know that if anything of value to man for his immediate needs is found, that reserve or potential reserve may be doomed. But if such a reserve was granted national status, where its title was set up, then maybe we could entrench it so that if they remove something they have got to replace it with something next door of a similar quality. But if it's done in bits and pieces here and there, you end up with different people going beyond what they really are aiming to do.

And then, of course, the major plea before I end: all of you must have been acutely aware that a small country like Malawi, since its independence, has taken the plunge and has put $11 \%$ of their land surface aside for conservation. We in South Africa have something like 2,2\% put aside. Surely, we must aim to get at least $10 \%$ of our country conserved and the reason for it is going to be that such land may still be the most valuable entity to conserve in the year 2000 or to rebuild what may have been destroyed at that stage.

Ladies and Gentlemen, I am sorry that I did not cover all the papers individually, but I think that the message that came out of the papers has been accentuated by me. May I, on behalf of the National Parks Board of Trustees, thank all of you who have participated - speakers and audience, for a very wonderful few days and once more thank the officials for what they have made of this occasion. Thank you. 